\title{
Solar Light Induced Photodegradation of Brilliant Green Dye by Barium Calciate $\left(\mathrm{BaCaO}_{2}\right)$ Nanoparticles
}

\author{
K. Nagendra Naik*, K. Yogendra*† and K. M. Mahadevan** \\ *Department of P. G. Studies and Research in Environmental Science, Kuvempu University, Jnana Sahyadri, \\ Shankaraghatta, Shimoga, Karnataka, India \\ **Department of Chemistry, Kadur P. G. Center, Kuvempu University, Kadur, Karnataka, India \\ $\dagger$ Corresponding author: Yogendra Kambalagere; yogendraku@gmail.com
}

\author{
Nat. Env. \& Poll. Tech. \\ Website: www.neptjournal.com \\ Received: 11-01-2020 \\ Revised: 28-01-2020 \\ Accepted: 05-03-2020 \\ Key Words: \\ Brilliant Green \\ $\mathrm{BaCaO}_{2}$ \\ Nanoparticles \\ Photocatalysis
}

\begin{abstract}
The study on photodegradation of Brilliant Green dye was done by barium calciate nanoparticles $\left(\mathrm{BaCaO}_{2}\right)$. The $\mathrm{BaCaO}_{2}$ was prepared by solution combustion synthesis. The analytical instruments like SEM, XRD, EDAX, and UV-absorption spectroscopy were employed for characterization. All the experiments were accomplished under various irradiation conditions such as sunlight, UV light and dark conditions. The obtained results examined the percentage of degradation capacity of $\mathrm{BaCaO}_{2}$ on Brilliant Green by differing the Brilliant Green concentration, $\mathrm{pH}$ and catalyst loading. The percentage of degradation was $98.93 \%$ in $20 \mathrm{ppm}$ of dye concentration at $\mathrm{pH} 6$ with a constant catalyst concentration of $0.7 \mathrm{~g} / 100 \mathrm{~mL}$. This proves that the synthesized barium calciate nanoparticles are more efficient in removing Brilliant Green from the wastewater.
\end{abstract}

\section{INTRODUCTION}

Recent industrial developmental activities are posing one or the other negative impacts on the environment, like the discharge of contaminants or discharge of coloured effluents directly into the environment. These coloured discharges impart severe pollution on the environment and cause health problems due to their toxicity and ability to sustain in nature (Arslan et al. 2000, Sauer et al. 2002). The dye effluents discharged into the water body decrease the aesthetic value of the water by colouring it. The sunlight penetration into the water body is blocked due to its colouring and inhibits the growth of useful biota (Yogendra et al. 2011). Due to low biodegradation characteristics and highly aromatic condition dyes have become prominent water pollutants (Madhusudhana et al. 2013, Daneshvar et al. 2004).

Recent studies have reported that wide ranges of metal oxide nanoparticles are being synthesized and their applications have made a unique contribution in the field of nanotechnology because of its unique and wide-ranging physicochemical properties (Di-Paola et al. 2003, Turchi et al.1990). Nowadays degradation of dye effluents using nanoparticles has attracted more attention of the scientific community (Mirkhani et al. 2009). The traditional methods like biological, physical and chemical are not so effective when compared to photocatalytic degradation. Advanced oxidation processes are promising alternatives for photodegradation of industrial effluents especially from the environmental point of view. Heterogeneous photocatalysis concentrates on the dissociation of dyes into simpler molecules of $\mathrm{CO}_{2}$, $\mathrm{H}_{2} \mathrm{O}$ and mineral acids by using metal oxide nanoparticles as catalysts (Vinodgopal et al. 1996, Movahedi et al. 2009). Hence, this work is a novel, simple and fast method to degrade the Brilliant Green dye by $\mathrm{BaCaO}_{2}$ nanoparticles under solar irradiation.

\section{MATERIALS AND METHODS}

Brilliant Green is an easily available dye in the market (Sigma Aldrich, Mumbai, India (Fig. 1). The chemicals (99\% A.R.), $\mathrm{Ba}\left(\mathrm{NO}_{3}\right)_{2}, \mathrm{Ca}\left(\mathrm{NO}_{3}\right)_{2}$ and $\mathrm{NH}_{2} \mathrm{CONH}_{2}$ were procured from Hi-Media Chemicals, Mumbai. Through visible spectrophotometer (Elico, SL 177) the absorbance was recorded at $\lambda$ max.

Nanoparticles synthesis: $\mathrm{BaCaO}_{2}$ nanoparticles were prepared using solution combustion methodology by redox mixtures of stoichiometric amounts of metal nitrates and fuel.

$$
\begin{aligned}
& 3 \mathrm{Ba}\left(\mathrm{NO}_{3}\right)_{2}+3 \mathrm{Ca}\left(\mathrm{NO}_{3}\right)_{2}+10 \mathrm{NH}_{2} \mathrm{CONH}_{2}^{-}=\mathrm{BaCaO}_{2}+ \\
& 10 \mathrm{CO}_{2}+20 \mathrm{H}_{2} \mathrm{O}+16 \mathrm{~N}_{2}
\end{aligned}
$$

XRD: The XRD of $\mathrm{BaCaO}_{2}$ is displayed in Fig. 2 as stated by Debye Scherrer's formula: 
<smiles></smiles>

Fig. 1: Chemical structure of Brilliant Green.

$$
\mathrm{D}=\mathrm{K} \lambda / \beta \operatorname{Cos} \theta
$$

Where, $\mathrm{K}=$ Scherrer's constant, $\lambda=\mathrm{X}$-ray wavelength, $\beta$ $=$ peak width at half-maximum, $\theta=$ Bragg's diffraction angle

In this work, the finely divided sample of $\mathrm{BaCaO}_{2}$ by XRD studies was found to have a size varied from $25 \mathrm{~nm}$ to $60 \mathrm{~nm}$ with an average size of $40 \mathrm{~nm}$.

SEM: Scanning Electron Microscope pictures of $\mathrm{BaCaO}_{2}$ nanoparticles have shown scattered crystals with irregular shapes. The magnified images also have shown a sharp-edged uneven texture of the different nanoparticles with strong bonding of nanoparticles over one another (Fig. 3).

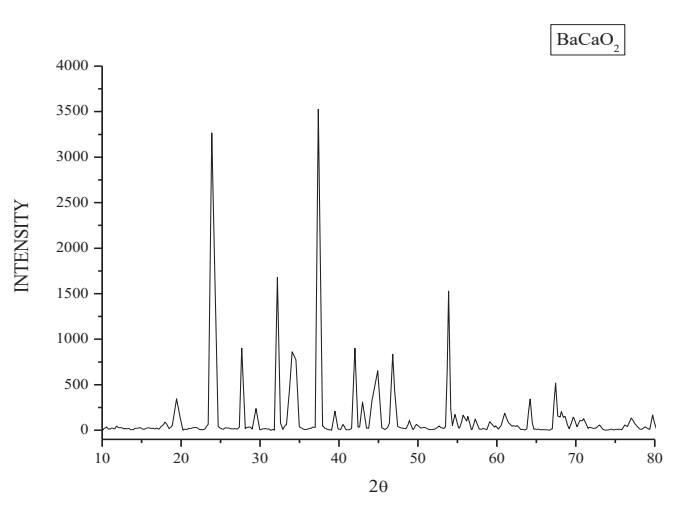

Fig. 2: XRD of synthesized $\mathrm{BaCaO}_{2}$ nanoparticles.

UV-Vis spectroscopy: Optical absorption is a significant tool to get the optical energy band gap of the nanomaterials. The elemental absorption related to the electron jump from the valence band to the conductivity band. The spectrum reveals that the $\mathrm{BaCaO}_{2}$ nanoparticle absorption in the visible radiation with a wavelength of $400 \mathrm{~nm}$ (Fig. 4). The value of optical band gap $(\mathrm{OBG})$ was calculated from the TAUC's relation:
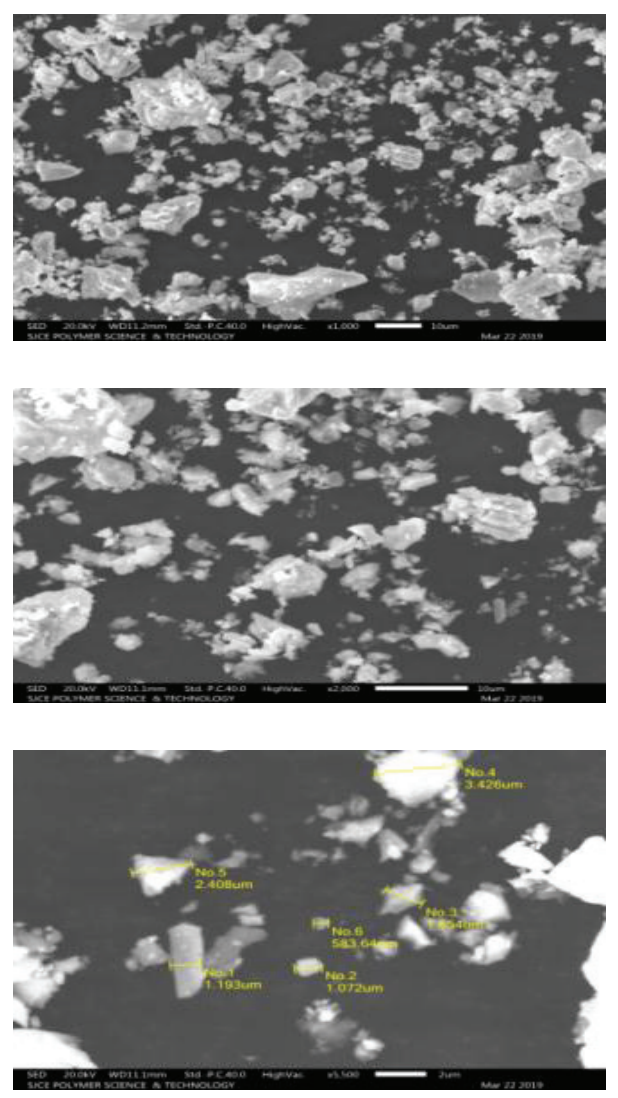

Fig. 3: Scanning Electron Micrographs of synthesized $\mathrm{BaCaO}_{2}$ nanoparticles. 
Table 1: Weight and atomic percentage of the elements in the barium calciate.

\begin{tabular}{|lll|}
\hline Element & Weight $\%$ & Atomic $\%$ \\
\hline $\mathrm{C}$ & 17.87 & 36.89 \\
$\mathrm{O}$ & 31.23 & 48.41 \\
$\mathrm{Ca}$ & 12.59 & 7.79 \\
$\mathrm{Ba}$ & 38.31 & 6.92 \\
\hline
\end{tabular}

$$
\begin{gathered}
\alpha h v=B \text { [hv }-E g] n \\
' h v '=\text { photon energy, } \\
' B '=\text { constant } \\
' n '=\text { power factor. }
\end{gathered}
$$

OBG of the $\mathrm{BaCaO}_{2}$ nanoparticle was found to be $3.57 \mathrm{eV}$.

EDAX: The EDAX analysis confirms the presence of $\mathrm{BaCaO}_{2}$, carbon and oxygen in the nanoparticle sample. The vertical axis displays the number of $\mathrm{x}$ counts although, the horizontal axis displays energy in $\mathrm{KeV}$ (Fig. 5). The weight and atomic percentage (Table 1) of carbon, oxygen, calcium, and barium were found to be $17.87,31.23,12.59,38.31$ and $36.89,48.41$, $7.79,6.92$ which correspond to the spectrum without impurities peaks.

\section{Experimental Procedure}

Using UV-visible absorption studies, the degradation of dye solutions was carried out. The spectral data noted using a spectrophotometer (Systronic UV-Visible) with 350-800

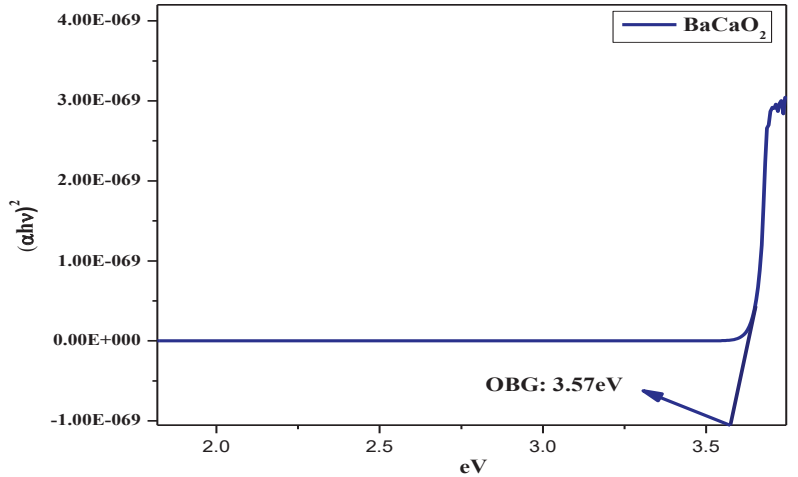

Fig. 4: UV-absorption spectra of synthesized barium calciate nanoparticles.

nanometre range. $492 \mathrm{~nm}$ was the maximum wavelength $(\lambda \max )$ of Brilliant Green. Solar irradiation is the main source for photocatalytic degradation experiments. The standard $(20 \mathrm{mg} / \mathrm{L})$ dye solution was made by mixing $20 \mathrm{mg}$ of Brilliant Green dye in 1 litre double distilled water. The dye solution then used for degradation experiments against $\mathrm{BaCaO}_{2}$ nanoparticle. Different parameters such as $\mathrm{pH}$ levels, dye concentration and $\mathrm{BaCaO}_{2}$ dosage were used to examine the degradation, and results were noted. $\mathrm{pH}$ balance of dye solution was maintained accurately by adding $\mathrm{HCl}$ or $\mathrm{NaOH}$. Finally, the colour degradation percentage was calculated using the formula as follows.

$$
\text { Decolorization }=\frac{\mathrm{V}_{0}-\mathrm{V}_{\mathrm{t}}}{\mathrm{V}_{0}} \times 100
$$
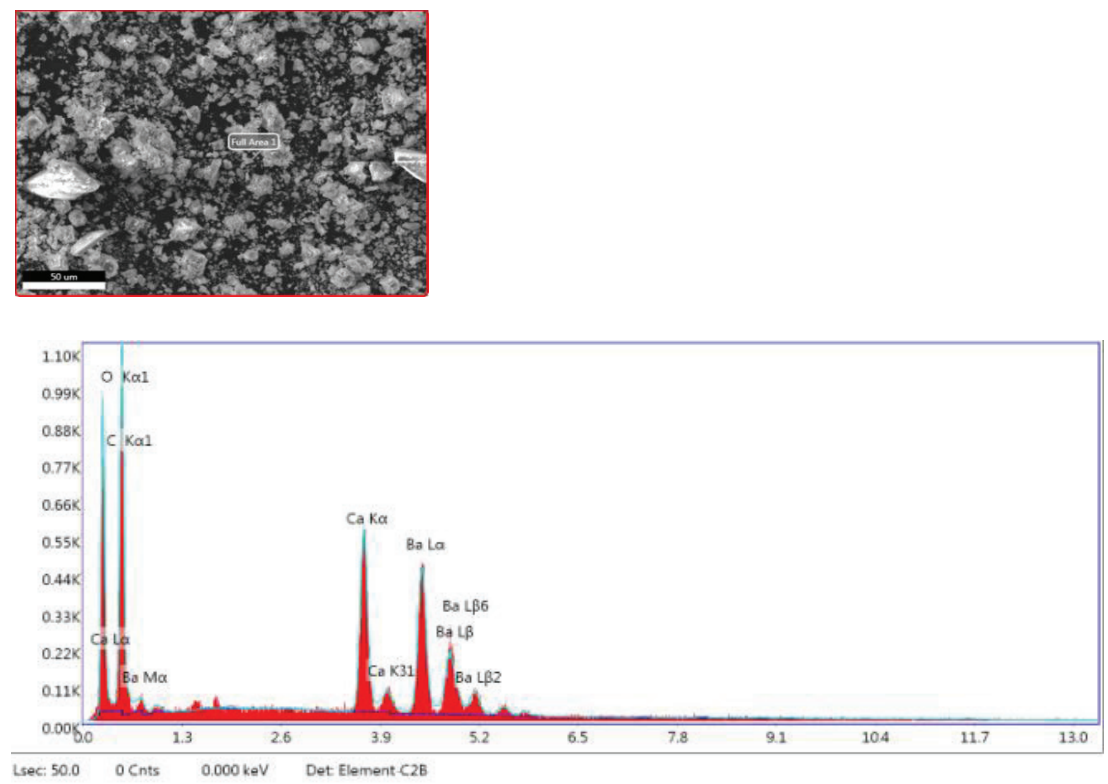

Fig. 5: Energy dispersive $\mathrm{X}$-ray of synthesized $\mathrm{BaCaO}_{2}$ nanoparticles. 
Where, $\mathrm{V}_{0}=$ initial absorbance of dye solution, $\mathrm{V}_{\mathrm{t}}=$ absorbance at time ' $\mathrm{t}$ '

\section{RESULTS AND DISCUSSION}

\section{$\mathrm{BaCaO}_{2}$ Dosage}

$\mathrm{BaCaO}_{2}$ dosage varied between $0.1 \mathrm{~g}$ and $1 \mathrm{~g} / 100 \mathrm{~mL}$ of selected dye solution and tested for its efficiency. The Ba$\mathrm{CaO}_{2}$ with the size $40 \mathrm{~nm}$ has shown $98.35 \%$ degradation. Since the photodegradation for the selected dye solution was highly successful at $0.7 \mathrm{~g} / 100 \mathrm{~mL}$ within 2 hours $(120 \mathrm{~min}-$ utes), further experiments were continued with the effective dosage of $0.7 \mathrm{~g}$ for all the remaining parameters. The results are shown in Fig. 6.

The degradation of Brilliant Green was maximum at 0.7 $\mathrm{g}$ due to the availability of optimum active sites on $\mathrm{BaCaO}_{2}$ surface area. In addition to this, the optimum sunlight into the solution and also a scattering of light by the catalyst also led to the photodegradation of the dye. Dosage level more than $0.7 \mathrm{~g}$ reduced the photodegradation due to overlying, overcrowding and collision with the ground state catalysts (Shanmugam 2006, Gandhi 2010, Thirugnanam 2017).

Hence, the dye molecules were degraded due to the high energy radicals formed in the reaction.

$$
\begin{gathered}
\text { Nanoparticles }+\mathrm{h} v \rightarrow(\mathrm{e}-\mathrm{CB}+\mathrm{h}+\mathrm{VB}) \\
\mathrm{e}^{-\mathrm{CB}}+\mathrm{O}_{2} \rightarrow \mathrm{O}_{2}^{\cdot-} \\
\mathrm{H}_{2} \mathrm{O}+\mathrm{O}_{2}^{\cdot-} \rightarrow \mathrm{OOH}^{\bullet}+\mathrm{OH}^{-} \\
2 \mathrm{OOH}^{\cdot} \rightarrow \mathrm{O}_{2}+\mathrm{H}_{2} \mathrm{O}_{2} \\
\mathrm{O}_{2}{ }^{--}+\mathrm{Brilliant}^{-} \text {green } \rightarrow \text { Brilliant green-OO} \\
\mathrm{O} \mathrm{OH}^{\cdot}+\mathrm{H}_{2} \mathrm{O}+\mathrm{e}^{-} \mathrm{CB} \rightarrow \mathrm{H}_{2} \mathrm{O}_{2}+\mathrm{OH}^{-}
\end{gathered}
$$

Hydrogen peroxide can be generated in another path.

$$
\begin{gathered}
\mathrm{H}_{2} \mathrm{O}_{2}+\mathrm{e}^{-} \mathrm{CB} \rightarrow \mathrm{OH}^{\bullet}+\mathrm{OH}^{-} \\
\mathrm{H}_{2} \mathrm{O}_{2}+\mathrm{O}_{2}^{\cdot-} \rightarrow \mathrm{OH}^{\bullet}+\mathrm{OH}^{-}+\mathrm{O}_{2}
\end{gathered}
$$

$\mathrm{OH}^{\bullet} / \mathrm{O}_{2}{ }^{-} /$Nano-particles ${ }^{+}+$Brilliant green $\rightarrow$ Brilliant green degradation ...9

\section{pH Effect on Brilliant Green}

For $\mathrm{pH}$ experiments, the range was set to 2, 4, 6, 8 and 10 for dye solutions. The degradation rate for the dye solutions has shown a remarkable increase from $97.36 \%$ to $98.93 \%$ with a $\mathrm{pH}$ change from 2-6 and a reduction up to $98.28 \%$ at $\mathrm{pH} 10$ (Fig. 7). An optimum degradation was achieved at $\mathrm{pH} 6$. The time required to achieve the degradation was 120 minutes at the optimum dosage of $0.7 \mathrm{~g}$ per $100 \mathrm{~mL}$ dye solution.

As the dye is a cationic compound which is very efficient in forming $\mathrm{OH} \cdot$ radicals in acidic solution, $\mathrm{OH} \cdot$ radicals are the main source of oxidation in carrying out photocatalytic degradation of Brilliant Green. Either positive or negative charge generate on the catalyst surface due to amphoteric effect and this is greatly influenced by changing $\mathrm{pH}$ value (Khan et al. 2017). In this reaction, the optimum amount of $\mathrm{OH} \cdot$ radicals were generated at $\mathrm{pH} 6$ in the solution. Acidic condition of solution less than $\mathrm{pH} 6$ has noted a reduction in degradation. The basic condition has an inhibition effect on Brilliant Green a cationic dye due to overproduction of $\mathrm{OH} \cdot$ radicals (Xiang et al. 2012, Liu 1999).

\section{Effect of Dye Concentration}

Experiments were conducted by differing the Brilliant Green dye levels from 20-50 ppm. The results for $\mathrm{BaCaO}_{2}$ are $98.93 \%$ for $20 \mathrm{ppm}, 93.39 \%$ for $30 \mathrm{ppm}, 88.7 \%$ for $40 \mathrm{ppm}$ and $87.36 \%$ for $50 \mathrm{ppm}$, respectively (Fig. 8). This has proved that photodegradation capacity directly depends upon the concentration of dye solution. An increased path length at lower dye concentration directly influences the increased photodegradation. At higher dye concentrations the path length ...7 reduces and hence less absorption of a photon by the catalyst. ...8 This results in a reduced photodegradation rate.

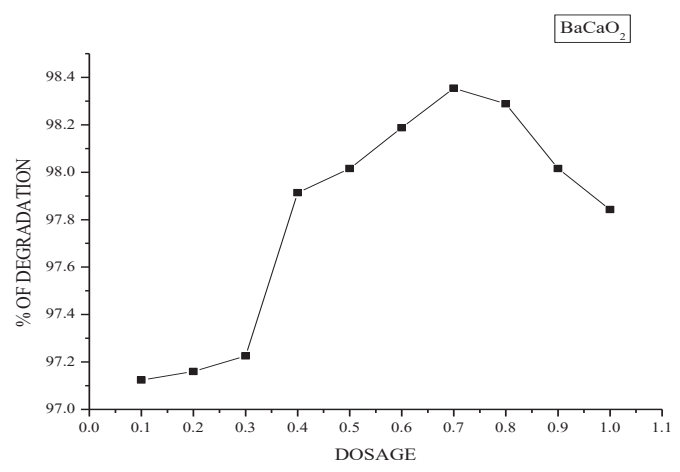

Fig. 6: Effect of catalyst concentration on Brilliant Green at 120 minutes (Brilliant Green=20 ppm, pH=6, $\mathrm{BaCaO}_{2}$ ). 


\section{Effect of Sunlight Irradiation}

Under three different conditions, i.e. through sunlight alone, dye-dark-catalyst, dye-UV-catalyst and dye-sunlight-catalyst experiments were conducted to check the nanoparticle efficiency. In sunlight alone, without catalyst, the photodegradation of Brilliant Green was noted almost nil. $98.93 \%$ of degradation achieved at dye-sunlight- $\mathrm{BaCaO}_{2}$ condition, $72 \%$ of degradation recorded at the dye-UV light- $\mathrm{BaCaO}_{2}$ condition and $54.04 \%$ degradation observed at dye-dark- $\mathrm{BaCaO}_{2}$ condition (Fig. 9). This clearly emphasizes the importance of different light conditions in the degradation of Brilliant Green dye.

The efficient photodegradation requires both sunlight as well as photocatalyst. The formation of electron-hole on the catalyst surface requires excitation of semiconductors. The sunlight gives the excitation energy to the semiconductors and thus efficient break down of organic dye molecule is achieved (Byrappa et al. 2006.)

\section{CONCLUSION}

As per the results, synthesized $\mathrm{BaCaO}_{2}$ has been proved to be photocatalytic and efficient in mineralizing the Brilliant
Green. The proposed photocatalytic method proved to be very effective for the degradation of Brilliant Green, an industrial dye. For the degradation experiment, we have achieved 98.93\% degradation at $\mathrm{pH} 6$. With this result, we can say that the application of nano-sized materials is more suitable for degradation of dye effluents. This will certainly help in solving the problem of the textile effluent treatment process.

\section{ACKNOWLEDGEMENT}

The authors would like to uphold their sincere thanks to the Department of Environmental Science, Kuvempu University and Government First Grade College, Shivamogga, Karnataka.

\section{REFERENCES}

Arslan, I. A., Balcioglu and Bahnemann, D.W. 2000. Heterogeneous photocatalytic treatment of simulated dye house effluents using novel $\mathrm{TiO}_{2}$-photocatalysts. Appl. Catal. B., 26: 193-206.

Byrappa, K., Subramani, A. K., Ananda, S.K., Lokanatha Rai, K., Dinesh, M. R. and Yoshimura, M. 2006. Photocatalytic degradation of Rhodamine B dye using hydrothermally synthesized ZnO. Bull. Mater. Sci., 29: 433-438.

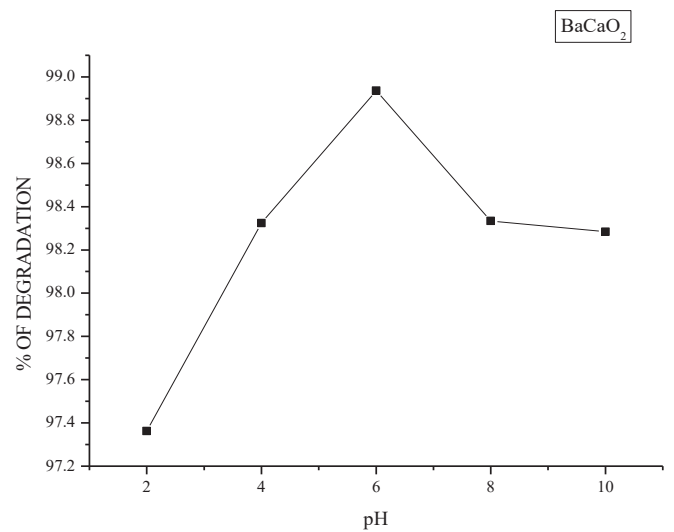

Fig. 7: Effect of $\mathrm{pH}$ on Brilliant Green at 120 minutes (Brilliant Green=20 ppm, $\mathrm{BaCaO}_{2}$ ).

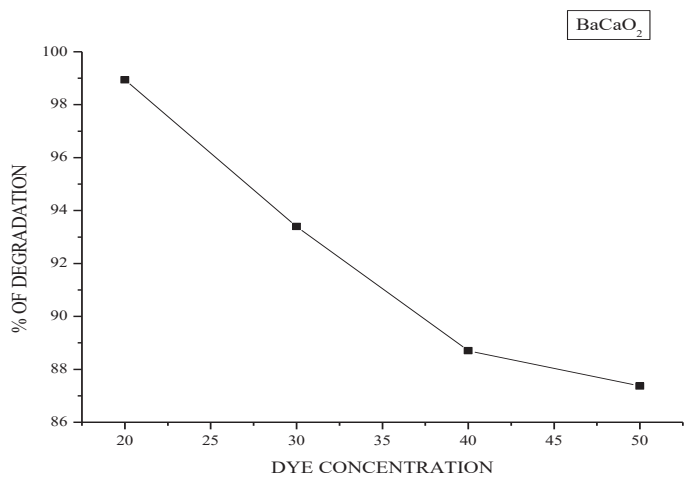

Fig. 8: Effect of dye concentration on the photodegradation of Brilliant Green $\left[\mathrm{BaCaO}_{2} \mathrm{~g} / \mathrm{pH}=0.7 / 4\right.$ and Brilliant Green $=(20+30+40+50)$ ppm $]$. 


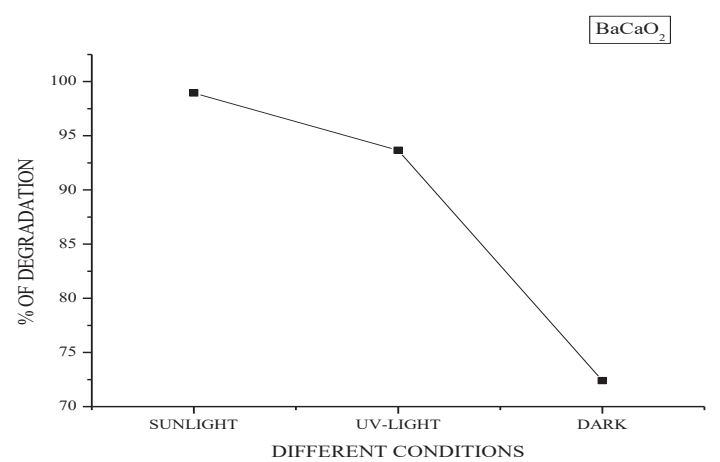

Fig. 9: Effect of sunlight irradiation with respect to the dark condition and UV condition on photocatalytic degradation of Brilliant Green in 120 minutes.

Daneshvar, N., Salari, D. and Khataee, A. R. 2004. Photocatalytic degradation of azo dye acid red 14 in water on $\mathrm{ZnO}$ as an alternative catalyst to $\mathrm{TiO}_{2}$. J. Photochem. Photobiol. A, 162: 317-322.

Di-Paola, Augugliaro, V., Palmisano, L. Pantaleo, G. and Savinov, E. 2003. Heterogeneous photocatalytic degradation of nitrophenols. J. Photochem. Photobiol. A, 155: 207-214.

Gandhi, J., Dangi, R., Sharma, J. C., Verma, N. and Bhardwaj, S. 2010. Photocatalytic bleaching of malachite green and Brilliant Green dyes using ZnS-CdS as semiconductor: A comparative study. Der Chemica Sinica. 1: 77-83.

Khan, Mamun Reza, Kurny, A.S.W. and Fahmida Gulshan 2017. Parameters affecting the photocatalytic degradation of dyes using $\mathrm{TiO}_{2}$ : A review. Appl. Water Sci., 7: 1569-1578.

Liu, danxia, W., Jing, L., Liping, 1999. The roles of free radicals in amyotrophic lateral sclerosis: reactive oxygen species and elevated oxidation of protein, DNA, and membrane phospholipids. The FASEB Journal. 2318-2328.

Madhusudhana, N., Yogendra, K. and Mahadevan, K.M. 2013. Photocatalytic decolourization of textile effluent by using metal oxide nanoparticles. J. Sci. Art., 3: 303-318.

Mirkhani, Tangestaninejad, S., Moghadam, M., Habibi, M. H. and Rostami Vartooni, A. 2009. Photocatalytic degradation of azo dyes catalyzed by Ag doped $\mathrm{TiO}_{2}$ photocatalyst. J. Iran Chem. Soc., 6: 578-587.

Movahedi, M., Mahjoub, A.R. and Janitabar-Darzi, S. 2009. Photodegradation of Congo Red in aqueous solution on $\mathrm{ZnO}$ as an alternative catalyst to $\mathrm{TiO}_{2}$. J. Iran Chem. Soci., 6: 570-577.
Sauer, T., Neto, G. C., Jose, H. J and Moreira, R. F. P. M. 2002. Kinetics of photocatalytic degradation of reactive dyes in a $\mathrm{TiO}_{2}$ slurry reactor. J. Photochem. Photobiol. A, 149: 147-154.

Shanmugam, N., Sathya, T., Viruthagiri, G., Kalyanasundaram, C. and Gobi, R. and Ragupathya, S. 2016. Photocatalytic degradation of Brilliant Green using undoped and $\mathrm{Zn}$ doped $\mathrm{SnO}_{2}$ nanoparticles under sunlight irradiation. Appl. Surf. Sci., 360: 283-290.

Thirugnanam, N., Song, H. and Wu, Y. 2017. Photocatalytic degradation of Brilliant Green dye using CdSe quantum dots hybridized with graphene oxide under sunlight irradiation. Chinese Journal of Catalysis, 38: 2150-2159.

Turchi, S. and Ollis, D. F. 1990. Photocatalytic degradation of organic water contaminants: Mechanisms involving hydroxyl radical attack. J. Catal., 122: 178-192.

Vinodgopal, K., Wynkoop, D.E. and Kamat, P.V. 1996. Environmental photochemistry on semiconductor surfaces: Photosensitized degradation of a textile azo dye, acid orange 7, on $\mathrm{TiO}_{2}$ particles using visible light. Environ. Sci. Technol., 30: 1660-1666.

Xiang, Q., Yu, J. and Jaroniec, M. 2012. Synergetic effect of $\mathrm{MoS}_{2}$ and graphene as cocatalysts for enhanced photocatalytic $\mathrm{H}_{2}$ production activity of $\mathrm{TiO}_{2}$ nanoparticles. J. Am. Chem. Soc., 134: 6575-6578.

Yogendra, K., Suneel Naik, Mahadevan, K. M. and Madhusudhana, N. 2011. A comparative study of photocatalytic activities of two different synthesized $\mathrm{ZnO}$ composites against Brilliant Green dye in presence of natural solar light. Int. J. Environ. Sci. Res., 1: 11-15. 